\title{
(2) Trade-restrictive Measures under the WTO aße Framework in the Context of the COVID-19 ResearchHouse Pandemic: The Example of China
}

\section{Yun ZHAO ${ }^{1}$, Lifei LIN ${ }^{2}$}

${ }^{1}$ Henry Cheng Professor in International Law and Head, Department of Law, The University of Hong Kong, Hong Kong ${ }^{2} \mathrm{PhD}$ Candidate, Faculty of Law, The University of Hong Kong, Hong Kong

E-mail for correspondence: zhaoy@hku.hk

\begin{abstract}
The COVID-19 outbreak has led to shortages of critical medical equipment and supplies, exposing significant flaws in the global supply chain. A number of countries have adopted trade-restrictive measures in response to the domestic challenges posed by COVID-19. This paper analyzes whether the trade-restrictive measures adopted by various countries in response to COVID-19 are legitimate under the current WTO framework and how to reform multilateral rules on such measures to promote global equality in accessing essential supplies and coping with the de-globalization wave.

With reference to China's practice, the paper first examines the compatibility of the trade-restrictive measures induced by COVID-19 with the WTO framework, arguing that export restrictions are likely permissible under WTO rules as long as they are non-discriminatory, temporary, and necessary to achieve a certain degree of domestic protection. However, such measures may ultimately disrupt global supply chains and cause more harm, especially to vulnerable countries. The COVID-19 crisis may even lead to a post-pandemic wave of economic de-Sinicization and de-globalization. The paper further argues that it will be contrary to the globalization trend for countries to implement a policy of supply chain localization in the post-pandemic era. The paper concludes that the best solution for minimizing the losses induced by similar crises in the future is to refer back to the WTO framework and reform the rules pertaining to trade-restrictive measures to promote equitable access to key global supplies.
\end{abstract}

Keywords: COVID-19, Trade-restrictive Measures, China's Response, WTO Reform; GATT; Global supply chain

\section{PART ONE: INTRODUCTION}

Free trade has long been hailed as an important mechanism for expanding competition and eliminating monopolies, which in turn promote efficiency and innovation. The increase in global trade, however, has been accompanied in recent years by the rise of emerging economies, most notably China, which is seen as a significant competitor to major developed economies such as the United States(US) and the European Union(EU). The theory of free trade has thus been called into question, particularly whether the

${ }^{1}$ Schillinger HR, 'In Need of Rethinking: Trade Policies in Times of De-Globalisation' (2016) Dialogue on Globalization Friedrich benefits of free trade have been overstated. Although the reversal of globalization could well damage economies in the long run, many developed economies have slowly shifted from a belief in the benefits of free trade to viewing it as "an issue that requires further consideration."

The outbreak of COVID-19, which led to shortages of critical medical equipment and supplies around the world, has exposed the vulnerability and flaws of the global supply chains resulting from increased free trade and globalization. Some countries have engaged in a zero-sum 
competition for essential goods and imposed unilateral export restrictions or prohibitions at the expense of their trading partners. The more vulnerable countries that rely on imported medical resources have suffered the most from these export restrictions. Under the current World Trade Organization (WTO) regime, countries usually invoke exception clauses to justify restrictive trade measures on the grounds of a "shortage of essential products" or "health risks."

Whether justified under WTO rules or not, the unilateral restrictive measures implemented in response to the COVID-19 crisis have exposed the vulnerability of crossborder supply chains. Such unilateral measures are by no means an ideal solution, with the WTO's multilateral mechanism likely to work better to help member states to break the deadlock and facilitate the distribution and coordination of supplies among trading partners under agreed circumstances. It is argued here that the world needs the WTO now more than ever and that a reformed WTO could be the perfect platform for meeting countries' needs via beneficial trade policies.

During the COVID-19 pandemic, China, given its sound industrial manufacturing chain and assumption of the bulk of global medical supply production capacity, has triggered fears among many countries over their overreliance on China for critical medical resources. The pandemic will inevitably lead to a global economic recession, which is almost certain to further deepen misunderstanding and hostility among countries and lead to the further rise of protectionism and nationalism. If that scenario proves true, it will have a negative impact on the current multilateral trading system, with the most direct result being the restructuring of the global industrial chain. It is believed that many countries will place greater emphasis on economic sovereignty and strict border controls after the pandemic, and decrease their reliance on China as the key product supplier and processing channel, which will lead to the gradual withdrawal of considerable production capacity from China. ${ }^{2}$ China thus needs to prepare itself for the economic de-Sinicization and deglobalization likely to occur in the post-epidemic era.

This paper takes up the task of examining whether traderestrictive measures in response to COVID-19 are legitimate under the current WTO framework, ways to reform the relevant WTO rules on such measures to

\footnotetext{
${ }^{2}$ Baldwin $\mathrm{R}$ and Tomiura E, "Thinking ahead about the trade impact of COVID-19" (2020) 59 Economics in the Time of COVID19.; Gereffi G, 'What does the COVID-19 pandemic teach us about global value chains? The case of medical supplies' (2020) 3 Journal of International Business Policy 287

${ }^{3}$ See the WTO website for a link to relevant information and statistical data: "COVID-19: Trade and trade-related measures", Available https://www.wto.org/english/tratop_e/covid19_e/trade_relat ed_goods_measure_e.htm(visited 22 September 2020).
}

promote global equality in access to essential supplies, and how the world should cope with the coming wave of deglobalization in the post-pandemic era.

Part 2 of the paper begins with a brief overview of the trade-restrictive measures implemented in response to COVID-19 and highlights the measures that fall within the ambit of WTO rules. After discussing whether the pandemic-induced measures are legitimate under the current WTO legal framework in Part 3, the paper turns in Part 4 to an examination of the trade measures that are relevant to China and discussion of how China can face the challenges of economic "de-Sinicization" and "deglobalization." Part 5 then analyzes the possibility of reforming the WTO's existing multilateral mechanism to find solutions to fragile cross-border supply chains and coordinate the distribution of materials among trade partners under special circumstances. Part 6 concludes that although trade-restrictive measures can be justified under the WTO regime, there is a necessity to further reform the WTO regime to cope with such special circumstances as a global pandemic.

\section{Part Two: Trade-restrictive Measures in RESPONSE TO COVID-19}

In dealing with the economic and public health impacts of the COVID-19 pandemic, many countries have adopted various trade restrictions or related measures, many of them with markedly nationalist characteristics. According to statistical data provided by the WTO, as of July 3, 2020, 83 countries and regions had taken a total of 216 trade or trade-related measures, covering both export and import areas. ${ }^{3}$ Sixty-four countries or regions have placed export control restrictions on personal protective equipment (PPE; e.g., mask, gloves) and certain medical products or equipment. ${ }^{4}$ Most of these export control measures, 108 in total, constitute temporary restrictions or prohibitions on particular drugs and medical devices and can be divided into two categories: licensing or permit requirements relating to exports and outright export prohibitions. For example, the US Federal Emergency Management Agency (FEMA) has implemented a temporary measure that restricts certain scarce or critical materials to being used to meet domestic demands only, with permission from FEMA required for any export of those materials. ${ }^{5}$ On

\footnotetext{
${ }^{4}$ See the WTO website for a link to relevant information and statistical data: "COVID-19: Trade and trade-related measures"(n 3 above); and ITC Market Access Map, Available at macmap.org/covid19\#based on media reports and official legislation.

${ }^{5}$ The rule covers five types of PPE: N-95 filtering facepiece respirators; other filtering facepiece respirators; elastomeric, airpurifying respirators and appropriate particulate filters/cartridges; PPE surgical masks; and PPE gloves or surgical gloves. See Department of Homeland Security - Federal Emergency Management Agency (44 CFR Part 328 - RIN 1660-
} 
April 1, 2020, China implemented licensing or permit requirements relating to exports of test kits and other medical supplies, which means that enterprises are required to obtain domestic quality certification before exporting them. ${ }^{6}$ China later expanded these licensing requirements to the export of non-medical masks and other medical supplies, requiring the conformance of such goods with either Chinese or foreign quality standards. ${ }^{7}$ The EU also issued rules requiring export authorization from EU member states to safeguard the supply of PPE from March 15 onwards. $^{8}$ As the situation evolves, similar export restrictions and measures may be placed on even more goods deemed "essential" for public health and economic purposes.

A very small number of countries have adopted trade liberalization measures concerning exports in response to COVID-19. For example, Argentina has temporarily eliminated export duties on raw hides and skins, leather, and fur skins ${ }^{9}$; Jamaica has reduced fees and charges in relation to the exportation of certain products; and Zambia has suspended export duties on precious metals and crocodile skins to provide relief to businesses. ${ }^{10}$ Although these export liberalization measures were taken to alleviate financial and business pressures and promote exports, there are other reasons for countries to lift or relax export restrictions already in place on essential medical supplies, which has led to controversies. For example, India's decision to ban the export of 26 pharmaceutical ingredients and medicines, including paracetamol and hydroxychloroquine, was rescinded in part to allow the

AB01): Prioritization and Allocation of Certain Scarce or Threatened Health and Medical Resources to Domestic Use, Federal Register/Vol. 85, No. 70 FR No. 20195 (10 April 2020) Available at https://www.govinfo.gov/content/pkg/FR-202004-10/pdf/2020-07659.pdf (visited 22 September 2020).

${ }^{6}$ See General Administration of Customs, Ministry of Commerce, National Medical Products Administration of the People's Republic of China: Announcement of the General Administration of Customs of the People's Republic of China national Medical Products Administration No.5 of 2020, Available at: http://www.gov.cn/zhengce/zhengceku/2020-

04/01/content_5497878.htm(visited 22 September 2020).

${ }^{7}$ General Administration of Customs, Ministry of Commerce, National Medical Products Administration of the People's Republic of China : Notice on Further Strengthening Export Quality Supervision of Pandemic Prevention Materials(Announcement of the General Administration of Customs of the People's Republic of China national Medical Products Administration No.12 of 2020), Available at:http:/ / www.gov.cn/zhengce/zhengceku/2020-

04/26/content_5506162.htm(visited 22 September 2020).

${ }^{8}$ WTO documents G/MA/QR/N/EU/4/Add.2, 7 May 2020; and G/MA/QR/N/EU/4/Add.3, 16 June 2020; and Commission Implementing Regulation (EU) 2020/568 (23 April 2020). Available at: https://eur-lex.europa.eu/legalcontent/EN/TXT/PDF/?uri=CELEX:32020R0568\&from=EN and export of certain formulations made from paracetamol under intense pressure from the US and Brazil. ${ }^{11}$ Further, as the COVID situation evolved, both Germany and Pakistan chose to lift their previous export bans on such medical supplies as textile masks and disinfectants. ${ }^{12}$

In the meantime, approximately 100 countries and regions have adopted roughly 129 temporary import measures. ${ }^{13}$ Unlike export measures, these measures to promote trade liberalization have primarily targeted PPE and medicines necessary to treat people infected with the virus or basic necessities such as food. The temporary import measures passed to date include tariff reductions or exemptions, the suspension of anti-dumping duties, and the simplification of customs clearance and administrative procedures for specific types of PPE, drugs, medical devices, and other medical materials imported from specific countries and regions. Such measures include both import promotion measures and import restriction measures. Among them, tariff relief is the most popular means of promoting the import of certain emergency supplies. For example, China temporarily reduced the import tariffs on certain products essential for economic and public health, such as medical materials, raw materials, and meat and agricultural products; the US lifted its ban on the import of rubber gloves from Malaysian companies; and both countries temporarily waived additional tariffs on certain products. ${ }^{14}$ In addition to tariff reductions, a number of countries, including Argentina, also suspended anti-dumping duties on the importation of certain essential medical products. ${ }^{15}$

https://trade.ec.europa.eu/doclib/press/index.cfm?id=2147_vis ited 22 September 2020)

${ }^{9}$ Argentina Decreto No. 549/2020 (DCTO-2020-549-APN-PTEDerecho de exportación) - Nomenclatura Común del Mercosur (22 June 2020).

${ }^{10}$ ITC Market Access Map, Available at: macmap.org/covid19\# (visited 22 September 2020) based on media reports and official legislation.

${ }^{11}$ Permanent Delegation of India to the WTO (1 May 2020) and Notification No. 50/2015-2020, Ministry of Commerce and Industry - Department of Commerce, Directorate General of Foreign.

${ }^{12}$ ITC Market Access Map (n 10 above).

${ }^{13}$ See the WTO website for a link to relevant information and statistical data: "COVID-19: Trade and trade-related measures" (n 3 above); ITC Market Access Map (n 10 above).

${ }^{14}$ State Administration of Taxation, the General Administration of Customs and the Ministry of Finance: Notice on the duty-free Policy for imported materials in the novel Coronavirus epidemic prevention and control ( Notice no. 6 of 2020 of State Administration of Taxation, the General Administration of Customs and the Ministry of Finance ) Available at: http:/ / www.gov.cn/zhengce/zhengceku/2020-

02/01/content_5473748.htm(visited 22 September 2020).

${ }^{15}$ Permanent Delegation of Argentina to the WTO (14 April 2020) and Resolución No. 114/2020 Ministerio de Desarrollo Productivo (20 March 2020). Available at: 


\section{Part Three: Legality of Trade-restrictive MEASURES Under THE WTO FrameWork}

Pursuant to Art. XI of the General Agreement on Tariffs and Trade (GATT), ${ }^{16}$ prohibitions or restrictions on the quantity of exported or imported goods belong to the category of Quantitative Restrictions (QRs) and should not be allowed. The WTO also imposes a notification obligation on countries that enforce new measures that could affect trade. However, it must be noted that there are exceptions to these rules under Art. XI:2, Art. XII, Art. XX, and Art. XXI of GATT, which provide possibilities for countries to take exceptional measures when the life and health of their people are at stake. ${ }^{17}$ The import and export trade measures discussed in the previous part of the paper are by nature QRs. It is thus necessary to examine their legitimacy within the WTO regime, in particular the possible application of Art. XI:2 and Art. XX to justify them. ${ }^{18}$

\section{Measures Covered by Art. XI:1}

As noted, WTO members have imposed a variety of trade restrictions in response to COVID-19, including measures prohibiting the import or export of certain medical supplies or protective equipment. Such restrictions, "other than duties, taxes or other charges," are considered unlawful under Art. XI of GATT. ${ }^{19}$ According to Art. XI:1, the term "quota" explicitly includes either an absolute export prohibition or a quantity limitation for essential export goods, meaning the export prohibitions and restrictions described above clearly fall within the scope of QRs under GATT. Imposing restrictions through licensing requirements on importation or exportation and other measures is also considered a violation of GATT Art. XI:1.

In addition to quotas and licensing requirements, other measures may also be governed by Art. XI:1. For example, the panel in Colombia - Ports of Entry concluded that the term "other measures" in that article encompasses a "broad residual category" and that any measures that result in "any form of limitation imposed on, or in relation to importation" would fall within the residual category of "other measures" in Art. X1:1. ${ }^{20}$ The panel further held that the ports of entry

https:/ / www.boletinoficial.gob.ar/detalleAviso/primera/22709 5/20200321?busqueda=1(visited 22 September 2020).

${ }^{16}$ General Agreement on Tariffs and Trade, LT/UR/A-1A/1, 14 April 1994(GATT).

17 Siddharth S Aatreya, "Are COVID-19 Related Trade Restrictions WTO-Consistent?" 25 April 2020 Available at https:/ /www.ejiltalk.org/ (visited 20 September 2020).

18 Siddharth S Aatreya ( $\mathrm{n} 16$ above).

${ }^{19}$ GATT, Art XI:1: “No prohibitions or restrictions other than duties, taxes or other charges, whether made effective through quotas, import or export licenses or other measures, shall be instituted or maintained by any contracting party on the importation of any product of the territory of any other contracting party or on the exportation or sale for export of any product destined for the territory of any other contracting party." measure, while not a quota or import license, could fall under the residual provision of Art. X1:1. ${ }^{21}$ Accordingly, "the residual category" could cover situations in which WTO member states stop or limit access to certain ports owing to public health concerns or increase fees in relation to importation or exportation to dissuade certain trading activities. Nevertheless, it is possible for a WTO member state to take trade-restrictive measures in certain circumstances, as will be further discussed in the next section.

\section{The Exception in Art. XI:2}

The first line of defense for a measure that might be considered unlawful under Art. XI:1 is the exception provided in Art. XI:2. The exception to the general prohibition pertaining to QRs contained in subparagraph(a) of that article is directly relevant here. Art. XI:2(a) stipulates that export restrictions adopted by member states will not be considered in violation of the prohibition under Art. XI:1 if the restrictions are "temporary" and intended to prevent or relieve "critical shortages" and if the targeted items are "foodstuffs or other essential products." ${ }^{\prime 2}$

The Appellate Body in China-Raw Materials provided clear guidance on the understanding of the terms "temporary," "applied to prevent or relieve," and "critical shortages." First off, the Appellate Body found that the term "temporarily" used to qualify "applied" in Art. XI:2(a) is to be defined as "lasting or meant to last for a limited time only; not permanent; made or arranged to supply a passing need" and, therefore, that the measures concerned should apply for a limited duration only and be adopted for the sake of bridging a "passing need." ${ }^{23}$ The Appellate Body also clarified that the term "temporarily applied" does not require the temporal scope of the measure to be fixed in advance. ${ }^{24}$ Thus, in this context, member states may adopt an export prohibition in response to a critical shortage of medical supplies under Art. XI:2(a) even if they do not designate a temporal scope or end date.

Further, according to the Appellate Body, the term "applied to prevent or relieve" indicates that measures may be adopted "to alleviate or reduce" an existing or imminent

${ }^{20}$ Colombia - Indicative Prices and Restrictions on Ports of Entry, WT/DS366/R, 27 April 2009, para 7.226-7.228.

${ }^{21}$ Ibid.

${ }^{22}$ GATT, Art XI:2: "[the] provisions of paragraph 1 of this Article shall not extend to the following: (a) Export prohibitions or restrictions temporarily applied to prevent or relieve critical shortages of foodstuffs or other products essential to the exporting contracting party."

${ }^{23}$ China - Measures Related to the Exportation of Various Raw Materials, WT/DS394/AB/R WT/DS395/AB/R WT/DS398/AB/R, 30 January 2012, para 323. See also Marceau, G. (2016). WTO and export restrictions. J. World Trade, 50, 563.

${ }^{24}$ Ibid., para 331. 
critical shortage. ${ }^{25}$ This interpretation allows member states to impose preventive or anticipatory measures such as precautionary export restrictions to stock up on essential medical products to prevent an imminent shortage during a pandemic. In addition, the Appellate Body interpreted the term "critical shortages" to refer to "deficiencies in quantity that are crucial and of decisive importance, or that reach a vitally important or decisive stage, or a turning point." ${ }^{26}$ It further explained that "critical shortages" in Art. XI:2 refers to foodstuffs or other "essential products" that are "absolutely indispensable or necessary" for the exporting country. ${ }^{27}$ The importance/necessity of medical supplies in the context of an epidemic is self-evident.

In accordance with the Appellate Body's findings discussed above, the export restrictions or prohibitions on medical products and PPE widely adopted by WTO members during COVID-19 can be considered to conform with the exceptions outlined in Art. XI:2(a) of GATT, as they were imposed in the event of critical shortages or for limited duration irrespective of whether the scope or end date was fixed. ${ }^{28}$ Although precautionary export restrictions implemented to stockpile essential medical supplies, if imposed temporarily, may also satisfy the exception defined in Art. XI:2(a), if taken out of excessive caution such measures may lead to chaos in international trade, particularly if the implementing country's domestic situation is not as urgent as that of other countries. Siddharth Aatreya has thus argued that such restrictions are unlikely to be justifiable under Art. XI:2(a) if the member state in question cannot demonstrate that the level of stockpiled essential goods is likely to become necessary during the course of the COVID-19 pandemic or in the near future. ${ }^{29}$

\section{General Exceptions in Art. XX}

Even if measures are considered to be unjustified under Art. XI:2(a), WTO members can still resort to the general exceptions outlined in Art. XX of GATT, which highlights certain situations in which members can deviate from their WTO commitments. Paragraphs (b), (i), and (j) of Art. XX are particularly relevant here. ${ }^{30}$ For the application of the general exceptions under Art. XX, member states are required to undergo a two-tier test: (a) the measure at issue

\footnotetext{
${ }^{25}$ Ibid., para 327.

${ }^{26}$ Ibid., para 324.

${ }^{27}$ Ibid., para 324.

${ }^{28}$ Marceau G (n 23 above), p 569.

${ }^{29}$ Siddharth S Aatreya (n 16 above)

${ }^{30}$ GATT, Art XX: (b) “ ... necessary to protect human, animal or plant life or health;

(i) involving restrictions on exports of domestic materials necessary to ensure essential quantities of such materials to a domestic processing industry; and

(j) essential to the acquisition or distribution of products in general or local short supply ..."

${ }^{31}$ United States-Standards for Reformulated and Conventional Gasoline, WT/DS2/R, 29 January 1996, para 6.20.
}

falls within one of the paragraphs of Art. XX, and (b) the measure is applied consistently with the requirements stipulated in the chapeau of Art. XX. ${ }^{31}$

Art. $\mathrm{XX}(\mathrm{b})$ is directly relevant to the COVID-19 context, and is thus used as an example in the analysis below. This article allows member states to take measures "necessary to protect the life or health of humans, animals or plants"; otherwise, they would be in violation of GATT obligations. For the first tier of the aforementioned two-tier test, WTO jurisprudence has established two steps of analysis for examining whether a measure falls within Art. XX(b). The first step is to ensure that the objective of the measure in dispute is "to protect human, animal or plant life or health." Obviously, this first step of analysis is relatively easy to satisfy, as almost all WTO members have taken prohibitive or restrictive measures to protect against COVID-19. The second step is to examine the "necessity" of the measure in dispute for fulfilling its policy objective. In addition to paragraph (b), paragraphs (a) and (d) have the same requirement for "necessity," and the aim in both is to prevent the abuse of exceptions. The term was first elaborated by the panel in US-Sect. 337 of the Tariff Act of 1930. In that case, the panel interpreted "necessity" as a situation in which no "WTO-consistent alternative measure" is available that a member state could "reasonably be expected to employ." ${ }^{32}$ Similarly, member states can take measures of the least degree of inconsistency with other GATT provisions ${ }^{33}$ only when no other measures that conform with GATT are available under reasonable circumstances. ${ }^{34}$ In other words, it would be difficult to justify a specific measure under Art. XX(b) if there were an alternative, less trade-restrictive measure that could achieve the same objective. The foregoing elaboration of the term "necessity" was later cited in Thailand-Cigarettes ${ }^{35}$ and US-Gasoline ${ }^{36}$ to determine whether a disputed measure was necessary.

However, the Appellate Body in Korea - Various Measures on Beef introduced additional elements to the necessity test, ${ }^{37}$ holding that determining the necessity of achieving the degree of protection is a holistic operation, of which whether

\footnotetext{
${ }^{32}$ Ibid., para 166.

${ }^{33}$ Ibid., para 165.

${ }^{34}$ United States_Sect. 337 of the Tariff Act of 1930, BISD 36S/345, 7 November 1989, para 5.26; see also United States-Measures Affecting Alcoholic and Malt Beverages, DS23/R, 19 June 1992, para 5.52.0.

${ }^{35}$ Thailand-Restrictions on Importation of and Internal Taxes on Cigarettes, BISD 37S/200, 20 February 1990, para 75; United States-Standards for Reformulated and Conventional Gasoline, WT/DS2/R, 29 January 1996, 6.25-6.28.

${ }^{36}$ Neumann J and Turk E, 'Necessity revisited: Proportionality in world trade organization law after Korea-Beef, EC-Asbestos and EC-Sardines' (2003) 37 Journal of World Trade 199, p 200.

${ }^{37}$ Ibid.
} 
it is "necessary" is "a process of weighing a series of factors." ${ }^{\prime 3}$ The Appellate Body further elaborated that these factors include "contribution to the achievement of the objective, the importance of the common interests or values, and the trade restrictiveness on imports or exports." ${ }^{39}$

Following the WHO's announcement of the COVID-19 pandemic, it is natural that the protection of people's lives would be considered of the utmost importance when it comes to balancing the interests and values at stake. With regard to consideration of the restrictiveness of measures, WTO members are encouraged to use legitimate measures that fall within the scope of GATT to the greatest extent possible or those that involve the lowest degree of violation in relation to GATT to protect humans, animals, and plant life or health. When it comes to the extent to which measures contribute to achieving that objective, it is to be examined on a case-by-case basis. It is worth noting that there is considerable flexibility here because member states have the right to determine the level of health protection that they deem appropriate. ${ }^{40}$ This principle is established in WTO jurisprudence. Although WTO members are not allowed to challenge one another's level of protection, they can question the necessity of measures taken to achieve that level. ${ }^{41}$ The same principle is also emphasized in the Technical Barriers to Trade Agreement (TBT Agreement) and Agreement on the Application of Sanitary and Phytosanitary Measures (SPS Agreement). ${ }^{42}$ In the COVID-19 context, WTO members may claim the need to maintain a relatively high level of public health protection, in which case the measures applied are likely to be considered without prejudice, and the controversial measures may also be considered legitimate to achieve a certain level of protection.

The second tier of the two-tier test considers whether a disputed measure is consistent with the chapeau of Art. $X X$, which stipulates that a measure constituting "arbitrary or unjustifiable discrimination between countries where the same conditions prevail" or a "disguised restriction on international trade" should be disallowed. ${ }^{43}$ The chapeau emphasizes "the manner in which [the] measure is applied" rather than its "specific contents." ${ }^{44}$

The chapeau contains two conditions. ${ }^{45}$ The first condition is that the specific measure in question does not discriminate arbitrarily or unreasonably between WTO members with the same conditions. The measures taken by members in response to COVID-19 apply uniformly to all

\footnotetext{
38 Korea - Various Measures on Beef, WT/DS161/AB/R WT/DS169/AB/R,11 December 2000, para 164.

${ }^{39}$ Ibid., para 164-165.

${ }^{40}$ Ibid., para 176.

${ }^{41}$ Ibid., para 176

${ }^{42}$ World Health Organization, World Trade Organization, \& World Trade Organization. Secretariat. "WTO Agreements \& Public Health: A Joint Study by the WHO and the WTO Secretariat" (World Health Organization 2002), p 32.
}

members, and thus the chapeau's first condition is satisfied. This would not be the case if some members made exceptions on a case-by-case basis or if certain measures had disproportionate effects on specific countries. However, a member can still provide justifications for a specific measure even if differences exist under the "same conditions" because the chapeau explicitly states that only "unjustifiable or arbitrary discrimination" is prohibited. The chapeau's second condition prohibits measures that are applied in a manner constituting a "disguised restriction on international trade." In US-Gasoline, the Appellate Body held that "disguised restrictions" encompass "disguised discrimination in international trade," including "hidden or undeclared restrictions or discrimination. ${ }^{\prime 46}$ However, the list is non-exhaustive, and thus there is still uncertainty over application of the term "disguised restrictions."

Nevertheless, there is a need to distinguish between the exceptions provided in Art. XX(b) and Art. XI:2(a). First, compared with Art. XI:2(a), the necessity test in Art. XX(b) does not restrict measures that apply "temporarily" over a broader time scope. In other words, long-term measures that fall within the scope of Art. $X X(b)$ are unlikely to be justified pursuant to Art. XI:2(a). Thus, the Art. XX(b) exception is most relevant to the case of the current pandemic, which will not disappear within a short period of time before the potential development of drugs/vaccinations. Second, Art. XI:2(a) covers only a "critical" shortage of "essential products." Under the necessity test in Art. XX(b), neither the element of a "critical" shortage nor that of "essential products" is required. Export restrictions, while failing to meet the requirement of temporary application and having the purpose of alleviating a critical shortage of essential goods, may still be justifiable under Art. XX(b). Accordingly, the Art. $X X(b)$ exception is more conducive to the adoption of long-term measures, taking into account WTO members' domestic population structure, level of public health infrastructure, and differing interpretations of how to ensure public health during the COVID-19 pandemic.

Although Art. XX provides a range of exceptions for export prohibitions or restrictions, their application is subject to certain conditions. For example, when it comes to Art. XX(j), which allows member states to impose restrictions in order to obtain an equitable share of the international supply of

\footnotetext{
${ }^{43}$ GATT, Preamble to Art XX

${ }^{44}$ United States-Standards for Reformulated and Conventional Gasoline, WT/DS2/ AB/R,20 May 1996, pages 22.

${ }^{45}$ Bartels L, "The chapeau of the general exceptions in the WTO GATT and GATS agreements: a reconstruction" (2015) 109(1) American Journal of International Law 95

${ }^{46}$ United States-Standards for Reformulated and Conventional Gasoline (n 39 above), page 25; See Klabbers J. 'Jurisprudence in International Trade Law-Article XX of GATT' (1992) 26 Journal of World Trade 63, p 77.
} 
certain products in short supply locally, such restrictive measures have a time limit and must conform with the principle that "Members are entitled to an equitable share in the international supply of such products. ${ }^{\prime \prime 7}$ If members are found to be unreasonably hoarding essential medical products through export restrictions that affect the ability of other members whose crisis is more severe to obtain an equitable share of those products, those restrictions may be rendered unjustifiable under Art. XX(j).

\section{National Security Exceptions in Art. XXI}

Art. XXI of GATT, which outlines national security exceptions, arguably provides further exceptions that may justify export restrictions in the COVID context. Art. XXI enables WTO members to implement measures necessary for national security interests or in the event of an "emergency in international relations." ${ }^{18}$ The challenge is how members can prove that their implementation of unilateral trade restrictions is necessary to protect their national security interests or that the prevailing background of COVID-19 constitutes an "emergency in international relations."

\section{WTO Agreements on the Application of Sanitary and Phytosanitary Measures and Technical Barriers to Trade}

In addition to GATT, two other WTO agreements are also relevant to public health protection under the WTO Framework: the aforementioned SPS Agreement and TBT Agreement. These two agreements stipulate public health protection as one of the legitimate objectives of a member state's adoption of certain trade-restrictive measures.

First, the SPS Agreement acknowledges that WTO members have a sovereign right to determine their own level of health protection, which means that members can temporarily implement necessary trade-restrictive measures on imports in the event of a disease outbreak or uncontrollable epidemic. However, such measures should not constitute unnecessary, arbitrary, scientifically unjustifiable, or disguised restrictions on international trade. ${ }^{49}$ The SPS Agreement offers further elaboration on the operation of rules concerning sanitary or phytosanitary

\footnotetext{
${ }^{47}$ GATT, Art XX(j); See Hoekman B, 'COVID-19 trade policy measures, G20 declarations and WTO reform1' Revitalising Multilateralism, p 65

${ }^{48}$ GATT, Art XXI: "Nothing in this Agreement shall be construed: (b)to prevent any Member from taking any action which it considers necessary for the protection of its essential security interests: ... (iii) taken in time of war or other emergency in international relations."

${ }^{49}$ Note 38 above, p 34

${ }^{50}$ Preamble to the Agreement on the Application of Sanitary and Phytosanitary Measures (SPS Agreement), WTO Agreement, Annex 1A, para 8. See Andemariam SW, "Can (Should) Article xx (b) GATT Be a Defense against Inconsistencies with the SPS and TBT Agreements?" (2006) 7 The Journal of World Investment \& Trade $519, \mathrm{p} 522$.
}

issues under GATT, in particular with regard to matters covered by Art. XX (b). ${ }^{50}$

The SPS Agreement also requires that member states justify their implementation of trade measures on the basis of scientific evidence showing an actual risk of endangerment to human life and health. ${ }^{51}$ Members should not take excessive measures without sufficient evidence or if those measures have the implied purpose of trade protection. The measures taken must be "necessary," "reasonable," "evidence-based," and "limited." Footnote 3 to the SPS Agreement also contains a necessity test, whereby any alternative measure must "achieve the appropriate level of sanitary or phytosanitary protection," be "reasonably available, while also taking into account technical and economic feasibility," and, finally, be "substantially less restrictive on trade." ${ }^{52}$ Comparatively speaking, the necessity standard in the SPS Agreement is relatively loose, giving member states greater leeway with respect to the definition of "reasonable availability" in terms of technical and economic feasibility. ${ }^{53}$ If scientific evidence sufficient to prove or assess the risk to human, animal, or plant life or health is unavailable, WTO members may take interim measures based on the available information on potential health risks. ${ }^{54}$ This stipulation is pertinent to the COVID-19 situation, as knowledge of the coronavirus remains limited, requiring in-depth scientific research in the future. However, the members concerned should specify the period that related measures will be in place and re-examine their scientific nature within a reasonable period of time. Otherwise, the measures could evolve into substantial trade barriers.

Second, the TBT Agreement also provides possibilities for WTO members to restrict trade for "legitimate purposes" to protect human health or safety. However, compared with the SPS Agreement, the legitimate purposes in the TBT Agreement are not limited to the protection of human health or safety, but also include protection of the environment and national security interests and the prevention of deception. ${ }^{55}$ The SPS and TBT Agreements, while sharing the common goal of preventing unnecessary trade barriers, differ in their substantive arrangements.

51 Pauwelyn J, 'The WTO agreement on sanitary and phytosanitary (SPS) measures as applied in the first three SPS disputes. EC-Hormones, Australia-salmon and Japan-varietals' (1999) 2 Journal of International Economic Law 641,p 645.

${ }^{52}$ SPS Agreement, Art 5.6 and footnote 3.

${ }^{53}$ Note 32 above, p 222; See also Marceau G and Trachtman JP, 'Technical Barriers to Trade Agreement, the Sanitary and Phytosanitary Measures Agreement, and the General Agreement on Tariffs and Trade, The' (2002) 36 Journal of World Trade 811

54 SPS Agreement, Art 5.7; Japan - Measures Affecting Agricultural Products, WT/DS76/AB/R, 22 February 1999, para. 89.

${ }^{55}$ Annex 1, paragraphs 1 and 2 of the TBT Agreement defines these two concepts. 
The SPS Agreement applies only narrowly to defined measures related to health protection. Scientific evidence is required to justify trade measures under the SPS Agreement, whereas scientific/technical information is only one of the relevant factors for consideration in assessing risks under the TBT Agreement. This discrepancy is reasonable, as risk assessment is a holistic exercise, whereas scientific information is essential in evaluating processing techniques and intended end-uses.

\section{Transparency-related Obligations}

WTO members must also fulfill a series of transparencyrelated obligations in imposing trade restrictions. Art. X:1 of GATT stipulates that members must promptly publish relevant prohibitions or restrictive measures concerning importation or exportation to ensure that other members and stakeholders have sufficient time to make the necessary adjustments. Such measures must also be administered "in a uniform, impartial and reasonable manner," as stated in Art. X:3(a). Pursuant to the "Decision on Notification Procedures for Quantitative Restrictions" (QR Decision), members are also required to notify the WTO Secretariat of all quantitative export restrictions as soon as possible. ${ }^{56}$ It should be noted that according to footnote 1 of the QR Decision, SPS and TBT measures are not covered. ${ }^{57}$ The transparency obligations pertaining to SPS measures are stipulated in Art. VII of the SPS Agreement. With regard to measures or any changes relating to sanitary or phytosanitary issues, member states must also provide notification and information in accordance with the provisions of Annex B. ${ }^{58}$

\footnotetext{
56 Art 1: "Members shall make complete notifications of all quantitative restrictions in force by 30 September 2012 and at two yearly intervals thereafter. They should also notify changes to those quantitative restrictions as soon as possible, but not later than six months from their entry into force." Decision on Notification Procedures for Quantitative Restrictions, G/L/59/Rev.1, 3 July 2012(QR Decision).

${ }^{57}$ QR Decision, Footnote 1:" These notification procedures are without prejudice to the rights and obligations of Members under the WTO Agreement. SPS and TBT measures, as well as automatic import licensing and tariff rate quotas (TRQs) are not covered by this Decision."

${ }^{58}$ SPS Agreement, Art 7.

${ }^{59}$ Siddharth S Aatreya (n 16 above)

${ }^{60}$ China implemented licensing or permit requirements on exports in response to COVID-19. For the exportation of test kits used for COVID-19, surgical masks, medical protective clothing, ventilators, and/or infrared thermometers, enterprises shall declare to customs and confirm that the export products in question have been granted the Certificate of Medical Equipment Product Registration in China and met the requirements of the quality standards of importing countries (regions) from April 1. With respect to the exportation of non-medical masks, from April 26 they must conform to either Chinese quality standards or foreign quality standards. For the exportation of test kits used for COVID-19, surgical masks, medical protective clothing,
}

Overall, the WTO-consistency of a given measure varies on a case-by-case basis, and is substantially influenced by such factors as the targeted products, domestic situation of the member implementing the measure, and the degree of protection intended to be achieved. Accordingly, measures taken by member states facing differing degrees of impact from COVID-19 and having differing demographic characteristics and differing levels of domestic medical equipment/drug production capacity and public health infrastructure may result in different outcomes if the aforementioned tests are applied. ${ }^{59}$ It should be noted that this part of the paper focuses only on the potential grounds for export restrictions or prohibitions and other related measures in response to COVID-19, not on the implications or legality of any specific measures.

\section{Part Four: China's Response to the Pandemic and De-globalization}

\section{Trade Policy Relevant to China during the Pandemic}

In response to COVID-19, China adopted two types of trade-related measures: restrictive measures and liberalizing measures. The restrictive measures it has adopted, as shown in Table 1 below, include licensing or permit requirements for the export of test kits and medical supplies, ${ }^{60}$ as well as prohibitions/restrictions on the import, trade, and consumption of all wildlife products for SPS reasons. ${ }^{61}$ Under Art. XI:1 of GATT, "export licenses" are considered to be a form of QRs. Prohibitions/import restrictions on wildlife trade obviously belong to the "prohibitions or restrictions" encapsulated in Art. XI of

ventilators, and infrared thermometers, China diluted the stipulation that the export products mentioned above must meet the requirements of the quality standards of importing countries (regions) according to a list of production enterprises registered or certified by foreign quality standards provided by the Ministry of Commerce. Both announcements added that the above export quality supervision measures for exportation will be adjusted dynamically according to the development of the pandemic.

${ }^{61}$ In the Wildlife Protection Act, regulations regarding the import and export of wildlife or wildlife products are stipulated in Art 35:

"The catalogues of wildlife or wildlife products whose trade is prohibited or restricted by the international conventions to which the People's Republic of China is a contracting party or acceding party shall be formulated, adjusted and published by the state administration for the import and export of endangered species."

The import and export of wildlife or wildlife products included in the list mentioned in the preceding paragraph and the export of wildlife under special state protection shall be subject to approval by the department of wildlife protection under the State Council or the State Council, and a permit for import and export issued by the state administration for import and export of endangered species shall be obtained. The customs shall carry out import and export quarantine according to law, and go through customs formalities according to regulations on the strength of import and export permit certificate and quarantine certificate." 
GATT. Neither restrictive measure constitutes "duties, taxes or other charges," and both are thus likely to be deemed inconsistent with Art. XI:1.

It is therefore necessary to examine whether China can invoke the exceptions discussed in the previous part of the paper to justify the two restrictive measures. The first line of defense is the carve-out in Art. XI:2 allowing export restrictions to be "temporarily applied to prevent or relieve critical shortages of foodstuffs or other essential products," which is the most relevant to the COVID-19 pandemic. However, this exception does not apply to prohibitions/restrictions on wildlife trade/imports, which have a long-term purpose, and neither does it appear to be fully applicable to export licensing measures.

It is true that the two restrictive measures meet the requirement of "temporariness." Although a specific end date for the measures is not explicitly stated, the announcements of both indicate that they can be repealed depending on the pandemic's development. Moreover, the targeted items, including test kits, surgical masks, non-medical masks, medical protective clothing, and ventilators, are "essential" products with respect to responding to the coronavirus. However, problems arise concerning the definition of the "necessity" to prevent or relieve "critical shortages" of foodstuffs or other "essential" products. In this regard, it must be noted that China has fully recovered its production capacity in the medical supply sector, with such supplies having reached peak production by April 2020. The direct reasons for taking the measures in question were to respond to media-reported complaints over the poor quality of such medical supplies as masks or test kits from China and to maintain a certain level of quality for those supplies. In this context, the move to restrict the quantity of medical supplies exported was not made for the purpose of preventing or relieving "critical shortages" domestically, as envisaged by Art. XI:2(a). Nevertheless, Art. XI:2(b) could arguably be relied upon for dealing with "restrictions related to the application of standards or regulations for the classification, grading or marketing of commodities in international trade." China could argue that its prohibition on the export of test kits, surgical masks, medical protective clothing, and ventilators that fail to meet the quality standards of both China and importing countries (regions) is necessary both to ensure the quality of essential medical supplies from China and to maintain the international market for them. ${ }^{62}$

In the case of failing to satisfy the exceptions in Art. XI, it is necessary to study the possibility of relying on the general exception in Art XX., in particular that in Art. XX(b), with

${ }^{62}$ The Panel Report on Canada - Measures Affecting Exports of Unprocessed Herring and Salmon examines Canada's claim that its regulations prohibiting the exportation of unprocessed sockeye and pink salmon and herring are permitted under Art XI:2(b), as the fish are "commodities" and the regulations deal with "standards" and "marketing." See Canada - Measures Affecting Exports of Unprocessed Herring and Salmon (L/6268 - 35S/98), 22 March 1988, para 3.4. regard to the necessity to protect human, animal, or plant life or health. As discussed above, two-tier analysis is required for use of the exception in Art XX(b). First of all, there is no doubt that the two restrictive measures adopted by China are directly related to the protection of public health and are consistent with the requirement that measures be taken for the purpose of "protecting human, animal or plant life or health." Second, with regard to the fulfillment of its policy objective, China could argue that the export licensing measures have been adopted to guarantee the quality of medical supplies and, in turn, to protect health or life. Furthermore, import prohibitions/restrictions on the wildlife trade, as an internationally recognized measure, are necessary to reduce the emergence of new animal viruses that can be transmitted to humans. At the moment, no other effective alternative measures exist to achieve that goal, and thus the necessity test can be satisfied. However, questions may arise as to whether the non-extraterritorial effect of import measures under Art. XX (b) applies equally to export licensing measures. It is normal for a country to adopt licensing measures for imported medical products to protect the life and health of its own people. In United States-Prohibitions on Imports of Tuna, for example, the panel held that import restrictions cannot be applied for the purpose of protecting the human, animal, and plant life and health of other countries; that is, such protective measures should not have extraterritorial effect. ${ }^{63}$ However, China's adoption of licensing measures on the export of medical products in the time of COVID-19 is a different matter. Thus, ambiguity exists concerning whether the non-extraterritorial effect condition also applies to export restrictions.

The second tier of the two-tier test involves the nondiscriminatory application of restrictive measures, as defined in the chapeau, which prohibits arbitrary or unjustifiable discrimination between countries with the same conditions or a disguised restriction on international trade. ${ }^{64}$ In the current scenario, the two restrictive measures adopted by China apply uniformly to all countries, and there is no evidence of disproportionate harm to any specific country where the same conditions prevail. Therefore, they are unlikely to be considered in violation of the chapeau's requirements.

In addition, in accordance with Art. 2.4 of the SPS Agreement, the two restrictive measures, once confirmed to be consistent with the SPS Agreement, will be deemed to comply with China's obligations under Art. XX (b) of GATT. Under the SPS Agreement, such measures may be considered consistent with relevant rules subject to a risk

${ }^{63}$ United States- Restrictions on Imports of Tuna, DS29/R, 16 June 1994, para 5.17; See Bartels L, "Article XX of GATT and the Problem of Extraterritorial Jurisdiction" (2002) 36 Journal of World Trade 353

${ }^{64}$ United States-Standards for Reformulated and Conventional Gasoline, WT/DS2/ AB/R,20 May 1996, pages 22-23 
assessment based on scientific evidence, taking into account the risk assessment techniques developed by relevant international organizations. Even in the absence of scientific evidence, a member state may take interim SPS measures on the basis of information available from relevant international organizations, as well as from other member states. Because import prohibitions/restrictions on all wildlife trade and consumption have been imposed globally, and are even reflected in several international treaties, ${ }^{65}$ it should be relatively easy for China to justify its compliance with the SPS Agreement and, in turn, its obligations under Art. XX (b) of GATT.

In addition to GATT and the SPS Agreement, China is also required to comply with specific national commitments under China's Accession Protocol. ${ }^{66}$ With regard to the question of reliance on Art. XX of GATT for a possible violation of China's WTO-Plus commitments ${ }^{67}$ on export duties in its Accession Protocol, reference can be made to the Appellate Body's ruling in China-Raw materials, which specifies that China has no legal basis to invoke Art. XX exceptions to justify export duties that are not in conformity with the commitments in paragraph 11.3 of the protocol. ${ }^{68}$ In other words, measures that are in violation of specific commitments made under China's Accession Protocol are unlikely to be supported by the general exception clause under GATT. In the case in question here, China's restrictive export measures do not fall within the scope of products China has committed to under paragraph 11.3 of its Accession Protocol.

Furthermore, paragraph 14 of China's Accession Protocol provides only for a notification obligation relating to SPS measures, namely, the obligation to notify the WTO of the country's laws, regulations, and other documents relating to sanitary and phytosanitary measures, including the scope of products and relevant international standards, guidelines, and recommendations. Although import prohibitions/restrictions on the trade of all wildlife are of a long-term nature, such measures could be justified through the general exception clause of GATT and the SPS Agreement. Such general exceptions, in particular the exception in Art. XI:2(b), could also be used to justify export licensing or permit requirements for medical supplies.

Table 1 : Restrictive Measures Adopted by China

\begin{tabular}{|c|c|c|c|}
\hline Types of Measure & Measures & Affected Countries & Status \\
\hline $\begin{array}{c}\text { Export licensing or } \\
\text { permit } \\
\text { requirement }\end{array}$ & $\begin{array}{l}\text { 1. April 1, 2020: China implemented export licensing or permit requirements for } \\
\text { test kits used for COVID-19, as well as surgical masks, medical protective } \\
\text { clothing, ventilators, and infrared thermometers. Exporting enterprises shall } \\
\text { declare to customs and commit that export products have been granted the } \\
\text { Certificate of Medical Equipment Product Registration in China and meet the } \\
\text { requirements of the quality standards of importing countries or regions. }{ }^{69} \\
\text { 2. April 26, 2020: non-medical masks for export must conform to either } \\
\text { Chinese quality standards or foreign quality standards. Test kits used for } \\
\text { COVID-19, surgical masks, medical protective clothing, ventilators, and } \\
\text { infrared thermometers that have been certified or registered in accordance } \\
\text { with foreign quality standards must meet the quality standards of importing } \\
\text { countries or regions. }\end{array}$ & All Countries & Effective \\
\hline
\end{tabular}

65 For example, the Convention on International Trade in Endangered Species of Wild Fauna and Flora (also known as the Washington Convention, hereinafter CITES). CITES works by subjecting the international trade in specimens of selected species to certain controls. All import, export, re-export, and introduction from the sea of species covered by the convention have to be authorized through a licensing system. As of October 2016, the convention had 183 parties, including 182 states and the European Union

${ }^{66}$ Accession of the People's Republic of China, Protocol on the Accession of the People's Republic of China, WT/L/432 (Nov. 23, 2001) [hereinafter China's Accession Protocol].

67 China's Accession Protocol contains one set of special provisions, which prescribe obligations exceeding the existing requirements of WTO agreements. Such obligations are also known as the "WTO-plus" obligations. Qin JY, 'WTO-Plus Obligations and Their Implications for the World Trade Organization Legal System' (2003) 37 J World Trade 483.

${ }^{68}$ China - Raw Materials, Panel Report, para 7.160; Appellate Body Report, para 307. See also Espa I, "Appellate Body Approach to the Applicability of Article XX GATT in the Light of China-Raw
Materials: a Missed Opportunity" (2012) 46 JOURNAL OF WORLD TRADE 1399; GUAN W, 'HOW GENERAL Should the GATT General Exceptions Be: A Critique of the Common Intention Approach of Treaty Interpretation' (2014) 48 Journal of World Trade 219, p 222; Liu Y, 'The Applicability of the General Exceptions to Export Duty Commitments in China: Rare Earths' (2014) 4 J WTO \& China 3, p 6.

${ }^{69}$ General Administration of Customs, Ministry of Commerce, National Medical Products Administration of the People's Republic of China: Announcement on orderly Export of Medical Supplies (Announcement of the General Administration of Customs of the People's Republic of China national Medical Products Administration No 5 of 2020) Available at: http://www.gov.cn/zhengce/zhengceku/202004/01/content 5497878.htm(visited 22 September 2020).

${ }^{70}$ General Administration of Customs, Ministry of Commerce, National Medical Products Administration of the People's Republic of China: Notice on Further Strengthening Export Quality Supervision of Pandemic Prevention Materials (Announcement of the General Administration of Customs of the People's Republic of China national Medical Products 


\begin{tabular}{|c|c|c|c|}
\hline Types of Measure & Measures & Affected Countries & Status \\
\hline $\begin{array}{c}\text { Import } \\
\text { prohibitions / restri } \\
\text { ctions for SPS } \\
\text { reasons }\end{array}$ & $\begin{array}{l}\text { Chinese officials issued an immediate and comprehensive ban on all } \\
\text { wildlife trade and consumption. }{ }^{71}\end{array}$ & All Countries & Effective \\
\hline
\end{tabular}

When it comes to liberalizing measures to facilitate the import of certain medical supplies, China has taken measures with wider coverage than those of other countries. As shown in Table 2, China has adopted measures to facilitate both the import and export of not only medical supplies, but also raw materials and agricultural products. The measures apply to all countries, with the exception of one that specifically targets the United States. It could thus be argued that China's tradepromotion policy aims to resolve the material shortage caused by COVID-19 on the one hand, and to facilitate the recovery of trade and the economy on the other, with the ultimate goal of re-consolidating China's central position in the global supply chain.

Table 2 : Liberalizing Measures Adopted by China

\begin{tabular}{|c|c|c|c|}
\hline $\begin{array}{l}\text { Types of } \\
\text { Measure }\end{array}$ & Measures & Affected Countries & Status \\
\hline $\begin{array}{l}\text { Tariff } \\
\text { reduction }\end{array}$ & $\begin{array}{l}\text { Certain products previously affected by the temporary tariff of the } \\
\text { United States will be temporarily exempted from the previously } \\
\text { increased } 10 \% \text { tax rate. }\end{array}$ & United States & $\begin{array}{l}\text { Effective from } \\
\text { February 28, } 2020 \text { to } \\
\text { February } 27,2021\end{array}$ \\
\hline $\begin{array}{l}\text { Tariff } \\
\text { reduction }\end{array}$ & $\begin{array}{l}\text { Temporary reduction of import tariffs on certain products, e.g., medical } \\
\text { supplies, raw materials, agricultural products, meat. }\end{array}$ & All Countries & Effective \\
\hline $\begin{array}{c}\text { Exceptional } \\
\text { measures }\end{array}$ & $\begin{array}{l}\text { The Ministry of Agriculture and Rural Affairs adopted nine facilitation } \\
\text { measures regarding three categories of agricultural administrative } \\
\text { approvals (license renewal, simplification of approval procedure, and } \\
\text { optimization of approval process) to prevent the further spread of the } \\
\text { virus. }\end{array}$ & All Countries & Effective \\
\hline $\begin{array}{l}\text { Electronic } \\
\text { export, } \\
\text { import, and } \\
\text { transit } \\
\text { procedures }\end{array}$ & $\begin{array}{l}\text { The Ministry of Commerce actively guides and encourages enterprises } \\
\text { to apply for import and export licenses in a paperless way, further } \\
\text { simplifies the materials required for digital applications of import and } \\
\text { export licenses, optimizes the application and update process of } \\
\text { electronic keys, and encourages enterprises to apply and update } \\
\text { electronic keys online. }\end{array}$ & All Countries & Effective \\
\hline Other & $\begin{array}{l}\text { Trade facilitation measures through the 127th Canton International Fair } \\
\text { online. }\end{array}$ & All Countries & Effective \\
\hline
\end{tabular}

During the time of the pandemic, other countries have also adopted trade-related measures, including both restrictive and liberalizing measures that specifically target China. As shown in Table 3, the restrictive measures are all related to import prohibitions/restrictions for SPS reasons. They target a wide range of products, but mostly live animals and plantbased products. Most of the measures were adopted during the initial stage of the COVID-19 pandemic in China, and some were terminated as the virus gradually came under control in China. As shown in Table 4, with regard to liberalizing measures targeting China, both Brazil and Argentina, in view of a domestic shortage of medical supplies, temporarily suspended anti-dumping duties on imports of hypodermic syringes from China. China and the United States also temporarily waived additional tariffs on certain products that had been imposed at the start of the "trade war" in 2019. The trade measures specifically targeting China during this period mainly covered products directly related to public health.

Administration No 12 of 2020) Available at: http://www.gov.cn/zhengce/zhengceku/2020-04/26/content_5506162.htm(visited 22 September 2020).

${ }^{71}$ With regard to prohibitions/restrictions on the wildlife import trade and consumption for SPS reasons, these are not entirely new measures in response to COVID-19, but were emphasized again in February 2020 by the Standing Committee of the National People's Congress. The Decision refers to the Wildlife Protection Act, which was enacted in 2018. 
Table 3: Selected Restrictive Measures Affecting China

\begin{tabular}{|c|c|c|c|c|}
\hline Country & Types of Measure & Measures & Affected Countries & Status \\
\hline Egypt & $\begin{array}{l}\text { Import } \\
\text { prohibitions / restrictions for } \\
\text { SPS reasons }\end{array}$ & $\begin{array}{l}\text { Temporary suspension of imports of } \\
\text { garlic, carrots, and green ginger from } \\
\text { China }\end{array}$ & China & $\begin{array}{l}\text { Effective from } \\
\text { February 9, } 2020\end{array}$ \\
\hline Kazakhstan & $\begin{array}{l}\text { Import prohibitions / } \\
\text { restrictions for SPS reasons }\end{array}$ & Import ban on Chinese fruits & China & $\begin{array}{c}\text { Effective from March } \\
2 \text { to April 22, } 2020\end{array}$ \\
\hline Georgia & $\begin{array}{l}\text { Import prohibitions / } \\
\text { restrictions for SPS reasons }\end{array}$ & $\begin{array}{l}\text { Import ban on live animals from } \\
\text { China }\end{array}$ & China & $\begin{array}{l}\text { Effective from } \\
\text { January 28, } 2020\end{array}$ \\
\hline Jordan & $\begin{array}{l}\text { Import prohibitions/ } \\
\text { restrictions for SPS reasons }\end{array}$ & $\begin{array}{l}\text { Temporary import ban on all animal } \\
\text { and plant-based products from } \\
\text { China. }\end{array}$ & China & $\begin{array}{l}\text { Effective from } \\
\text { February 2, } 2020\end{array}$ \\
\hline Mauritius & $\begin{array}{l}\text { Import prohibitions/ } \\
\text { restrictions for SPS reasons }\end{array}$ & $\begin{array}{l}\text { Temporary import restrictions on live } \\
\text { animals, including fish, from certain } \\
\text { countries }\end{array}$ & $\begin{array}{l}\text { China, Italy, Iran, } \\
\text { South Korea, } \\
\text { Switzerland, } \\
\text { Reunion Island, and } \\
\text { the European Union }\end{array}$ & $\begin{array}{c}\text { Effective from March } \\
16 \text { to June } 3,2020\end{array}$ \\
\hline $\begin{array}{l}\text { Russian } \\
\text { Federation }\end{array}$ & $\begin{array}{l}\text { Import } \\
\text { prohibitions } / \text { restrictions for } \\
\text { SPS reasons }\end{array}$ & $\begin{array}{l}\text { Temporary import restrictions on } \\
\text { exotic and decorative animals, } \\
\text { including insects, arthropods, } \\
\text { amphibians, reptiles, and other, live } \\
\text { fish and hydrobionts from China } \\
\text { (active since January 30, 2020; } \\
\text { extended on February 18, 2020) }\end{array}$ & China & $\begin{array}{c}\text { Effective from } \\
\text { January } 30 \text { to May 21, } \\
2020\end{array}$ \\
\hline
\end{tabular}

Table 4: Selected Liberalizing Measures Affecting China

\begin{tabular}{|c|c|c|c|c|}
\hline Country & Types of Measure & Measures & Affected Countries & Status \\
\hline $\begin{array}{l}\text { United } \\
\text { States }\end{array}$ & Tariff reduction & $\begin{array}{l}\text { Temporary exemption of the } 25 \% \text { surcharge on } \\
\text { certain products from China }\end{array}$ & China & $\begin{array}{l}\text { Effective from September } \\
\text { 1, } 2019 \text { to September } 1 \text {, } \\
\text { 2020; published on } \\
\text { March 20, } 2020 \text { but } \\
\text { effective retroactively } \\
\text { from September 1, } 2019\end{array}$ \\
\hline Brazil & $\begin{array}{l}\text { Suspension of } \\
\text { anti-dumping } \\
\text { duties }\end{array}$ & $\begin{array}{l}\text { Temporary suspension of anti-dumping duties on } \\
\text { vacuum plastic tubes for blood collection and } \\
\text { syringes from China and certain other countries } \\
\text { owing to COVID-19 }\end{array}$ & $\begin{array}{l}\text { China, Germany, } \\
\text { the United } \\
\text { Kingdom, and the } \\
\text { United States }\end{array}$ & $\begin{array}{c}\text { Effective from March } 25 \\
\text { to September 30, } 2020\end{array}$ \\
\hline Argentina & $\begin{array}{c}\text { Suspension of } \\
\text { anti-dumping } \\
\text { duties }\end{array}$ & $\begin{array}{l}\text { Temporary suspension of anti-dumping duties on } \\
\text { imports of hypodermic syringes made of plastic, } \\
\text { disposable, sterile, with or without needles from } \\
\text { China (investigation initiated on September } 15,2009 \text {, } \\
\text { with definitive duty imposed on March } 15,2011 \text { ) }\end{array}$ & China & $\begin{array}{l}\text { Effective from March 21, } \\
2020\end{array}$ \\
\hline
\end{tabular}

The two tables above show that a number of countries took measures whose main purpose was to cope with shortages of medical supplies resulting from the pandemic. China's aims in adopting relevant measures, in contrast, have been to support the recovery of the domestic economy and help to restore its central position in the global supply chain during the pandemic.

\section{Wave of Economic De-Sinicization and De- Globalization}

A direct impact of the COVID-19 pandemic has been to restructure the global industrial chain. Many countries have expressed serious concern about their overreliance on China for critical medical resources during the pandemic. Going forward, they may further emphasize economic 
sovereignty and appropriate border controls, leading to decreased reliance on China as their primary product supplier and processing channel once the pandemic has abated. Accordingly, China is likely to face a wave of economic de-Sinicization and de-globalization in the postepidemic era.

China's influence over the global supply chain may be constrained after the pandemic in two respects. In a narrow sense, countries may transfer product suppliers and processing channels to countries or regions with relatively low labor costs, such as Southeast Asian countries, to reduce their reliance on China. In a broader sense, countries may localize the production of essential materials and adopt a self-sufficient mode to drive manufacturing and service industries back to their domestic markets, which is in essence a de-globalization process.

To predict the possible scale of these phenomena, it is necessary to look into the factors and advantages that have afforded China its important role in the global supply chain and examine whether such advantages are replaceable. First, China is not simply a production and supply base for the world; it is also the world's major market with the largest number of consumers. An enterprise whose entire supply and industrial chain is based in China enjoys the flexibility to meet the domestic demands of the Chinese market. Second, with competitiveness based on labor costs declining, the sheer scale of the Chinese market can serve as a key driver to push down comparative production costs. These two factors should help China to maintain its central position in the global manufacturing market. The downstream assembly operations of some low-cost, labor-intensive products may move to other Asian countries in the future, but such restructuring of assembly operations will not marginalize China. On the contrary, it will help to form a closer regional supply chain system. In other words, the global supply chain and value chain are indeed undergoing market-oriented restructuring, but China will maintain its central position during the restructuring process and move steadily toward globalization through strengthened regional cooperation.

Stronger regional cooperation is vital not only to consolidate the existing significant position of East Asia in the global supply chain, but also to restructure future supply chains in Asia. As Baldwin and Tomiura observe, China, Japan, and South Korea are well-positioned at the core of the global supply chain for most manufactured products, with China the heart of the so-called "Asian factory" and the "OPEC of industrial input." 72 For example, in the ICT sector, we can witness the centrality of China, with relatively strong regional reliance. ${ }^{73}$ The three aforementioned countries are the manufacturing giants of

\footnotetext{
${ }^{72}$ Baldwin R and Tomiura E (n 2 above).
}

${ }^{73}$ Ibid.
East Asia, accounting for more than 25 percent of US imports generally and more than 50 percent of US imports of computers and electronics specifically. ${ }^{74}$ Accordingly, China will ultimately benefit by consolidating the essential position of East Asia in the global supply chain.

The de-globalization process will reduce global supply chain reliance on China. Greater self-sufficiency will require the localization of countries' supply chains. However, in today's globalized world, it is unrealistic for any economy, whether developed, developing, or emerging, to rely solely on self-sufficiency to deliver a domestic supply of public health resources. No country can be completely self-sufficient in the supply of products and equipment needed by its public health system, especially during a pandemic. Even China, the world's major supplier of medical materials, still needed to import a large quantity of medical supplies to meet its domestic needs at the early stage of the pandemic. Moreover, because internationalization of the supply chain serves the purpose of improving productivity, the reverse would do the opposite. Therefore, multilateral cooperation is needed to prevent undue restrictions on basic medical services, essential necessities, and global supplies through uncoordinated national blockades.

The global supply chain is the result of trade globalization. China has benefited from globalization to occupy an important position in the global supply chain, and globalization and multilateralism remain the best ways of dealing with de-Sinicization. The WTO, as the most important representative of the multilateral trading system, remains the best platform for helping China to cope with the expected wave of de-Sinicization and deglobalization. The defects in the global supply chain exposed during the pandemic can best be dealt with through amendments to existing multilateral trading rules, further clarification, and the prevention of abuses of the exceptions to such rules.

\section{Part Five: Reforms to the WTO Regime in the PANDEMIC CONTEXT}

The foregoing analysis shows that WTO members can take trade-restrictive measures relating to PPE and medical materials by invoking exceptions contained within WTO rules. However, such restrictive measures have the potential to cause disruptions to the global supply chain, with severe consequences for countries that rely heavily on the import of medical resources. Under the current multilateral regime, cross-border supply chains are particularly vulnerable during times of pandemic. There is thus an urgent need to reform that regime. Resorting to the multilateral regime rather than the adoption of unilateral export controls for a solution can help to resolve the root

${ }^{74}$ Ibid. 
problem. ${ }^{75}$ It is argued here that a reformed WTO would be the best platform for coordinating trade policies among WTO member states.

\section{Narrower Use of Exceptions to Existing Trade Rules}

a. Restrictive interpretation of the exception in GATT Art. $X I: 2(a)$

GATT Art. XI:2(a) provides an exception to QRs, allowing export prohibitions or restrictions to be temporarily applied for the purpose of preventing or relieving critical shortages of essential products. The term "temporarily applied," as interpreted by the Appellate Body, does not require prior determination of the time period. ${ }^{76}$ Accordingly, temporary precautionary export restrictions implemented to stockpile essential medical supplies are permissible under Art. XI:2(a). However, the severity of the pandemic differs from country to country, depending on the actual and predicted course of the epidemic, the size of the population, domestic medical device/drug production capacity, and public health infrastructure, among other factors. Preventive export prohibitions or restrictions and the stockpiling of essential medical supplies by countries with relatively strong capacity and a less severe epidemic status may adversely affect those with weaker domestic capabilities to produce essential medical supplies, particularly if they are suffering a more serious pandemic.

Therefore, the exception in GATT Art. XI:2(a) should be applied with great caution, particularly with respect to adopting preventive export restrictions to ease an imminent critical shortage. Rather, that article should be interpreted narrowly. Taking the pandemic as an example, a country intending to apply the Art. XI:2(a) exception should take into account its own domestic circumstances, including its ability to produce essential medical supplies, and comprehensively analyze whether its quantitative deficiencies in medical supplies have reached a turning point from both the domestic and international perspectives. $^{77}$

\footnotetext{
${ }^{75}$ Bueno De Mesquita J and Mason Meier B, 'Moving towards global solidarity for global health through multilateral governance in the COVID-19 response' (2020); Brown G and Susskind D, 'International cooperation during the COVID-19 pandemic' (2020) 36 Oxford Review of Economic Policy S64

${ }^{76}$ China - Measures Related to the Exportation of Various Raw Materials, $\quad \mathrm{WT} / \mathrm{DS394/AB/R} \quad \mathrm{WT} / \mathrm{DS395} / \mathrm{AB} / \mathrm{R}$ WT/DS398/AB/R, 30 January 2012, para 331. See also Marceau, G (n 23 above), p563.

${ }^{77}$ Siddharth S Aatreya (n 16 above).

${ }^{78}$ GATT, Art X:1, Art X:3(a); QR Decision, Art 1; SPS Agreement, Art VII.

${ }^{79}$ WTO Agreement on Agriculture, Art 18.
}

\section{b. Increased transparency in the adoption of trade- restrictive measures}

WTO members are required to notify the WTO Secretariat without delay when adopting any QR measures. ${ }^{78}$ For any measures relating to foodstuffs, they should also notify the Committee on Agriculture. ${ }^{79}$ However, thus far, only 39 members, including 27 from the EU, have notified the WTO of QRs, with three notifications on the adoption of export restrictions on foodstuffs pursuant to Art. 12 of the Agreement on Agriculture. ${ }^{80}$ Insufficient information will inevitably result in a high degree of uncertainty for market participants and member states. ${ }^{81}$ A lack of transparency in a time of pandemic will further lead to market disorder in the purchase and delivery of medical supplies for emergency purposes, thereby reducing the efficiency of counties' efforts to cope with the pandemic. It is thus necessary to advocate for increased transparency concerning any trade-related restrictive measure. The WTO has put forward several proposals on improving transparency, including the publication of new trade measures at the national level and, where possible, on the websites of relevant national authorities. ${ }^{82}$

A joint document initiated by the EU and co-sponsored by Australia, Canada, Chile, and Japan, has been submitted to the WTO Trade Policy Review Body for consideration. The document reiterates the importance of WTO members leading by example in fulfilling their notification obligations and calls upon members to issue notifications as far in advance as practicable and cooperate with the WTO Secretariat in its monitoring work. ${ }^{83}$ In addition, the aforementioned member states also urged the Secretariat to provide technical assistance to members that need help in fulfilling their notification obligations during the pandemic. ${ }^{84}$ The document lists several specific measures, including: a) following the practice, put in place during the financial crisis, of issuing quarterly trade monitoring reports; b) incorporating trade-related economic support measures in trade monitoring reports; and c) making technical assessments of members' trade-related economic support measures relating to COVID-19, in particular with regard to the number of members that have taken relevant

\footnotetext{
${ }^{80}$ WTO : INFORMATION NOTE -EXPORT PROHIBITIONS AND RESTRICTIONS, Available at At:https://www.wto.org/english/tratop_e/covid19_e/export_ prohibitions_report_e.pdf (visited 22 September 2020).

${ }^{81}$ Ibid.

${ }^{82}$ Ibid.

83 COVID-19: TRANSPARENCY OF TRADE-RELATED MEASURES, COMMUNICATION FROM AUSTRALIA, CANADA, CHILE, EUROPEAN UNION, JAPAN, KOREA, MEXICO,NEW ZEALAND, NORWAY, SINGAPORE, SWITZERLAND, Available at: https: / / trade.ec.europa.eu/doclib/press/index.cfm?id=2172 (visited 06 NOV 2020).

${ }^{84}$ Ibid.
} 
measures, the measures taken, and sources of relevant information. ${ }^{85}$

Some countries, including Australia, believe that, in addition to regular notifications, WTO members, developed countries in particular, should be encouraged to submit ad hoc reports on measures related to COVID-19 and recommend that all large and emerging economies should follow suit. ${ }^{86}$ However, WTO members hold divergent views on how to improve transparency. Some have expressed concern over possible duplication between interim reports and the Secretariat's monitoring work, and some developing members hold the view that the interim report mechanism does not work well for developing countries, and hence that members should be free to adopt whatever form of notification best fits their actual domestic circumstances. ${ }^{87}$ Some members have also cautioned that the interim report mechanism, unlike the monitoring mechanism, is essentially voluntary in nature, and thus should not invoke a penalty for non-compliance. ${ }^{88}$

c. Safeguarding the rights and interests of developing and less developed countries in accessing essential products

Trade restrictions, especially export bans and restrictions on medical supplies during a pandemic, have a severe impact on developing countries with vulnerable economies that rely heavily on imported medical supplies. In today's globalized world, countries should, as far as possible, open their supply chains to developing and less developed countries subject to first satisfying their own domestic needs. The EU sets an excellent example in offering assistance to developing and less developed countries through the provision of free technical standards for certain medical devices and equipment and speeding up the production of supplies related to epidemic prevention and control.

\section{Further Liberalization and Facilitation of the Trade in Goods}

\section{a. Trade liberalization in response to the pandemic}

It should be noted that in light of the challenges to international trade during the pandemic, many countries have adopted measures to promote trade liberalization instead of placing restrictions on trade. These measures have helped to promote global trade and restore global supply chains.

\footnotetext{
${ }^{85}$ Ibid.

${ }^{86}$ WTO: WTO members push for increased transparency on COVID-19 measures in farm trade, Available at https://www.wto.org/english/news_e/news20_e/agri_28jul20 _e.htm (visited 06 NOV 2020).

${ }^{87}$ Ibid.

${ }^{88}$ Ibid.

${ }^{89}$ WTO Trade Facilitation Agreement, WT/L/940, 28 November 2014, Art 7 and Art 8
}

Most of the liberalization measures adopted to date are intended to promote imports, such as the cancellation or reduction of tariffs, the temporary suspension of antidumping duties, and the simplification of administrative procedures for the import of certain PPE, medicines, medical devices, and other essential medical supplies from specific countries and regions. There have also been some measures intended to promote exports. For example, Argentina temporarily lifted export duties on hides and furs during the pandemic; Jamaica cut export-related taxes; and Zambia suspended export duties on precious metals and crocodile skins to ease the pressure on businesses.

\section{b. Facilitation of the trade in goods}

The WTO Trade Facilitation Agreement is playing an important role in coping with the challenges brought about by the global pandemic. For example, the agreement includes such suggestions as the provision of a "green channel," rapid inspection and cargo release, priority inspection and review, and shortened customs clearance procedures for the import of essential products, especially drugs and medical equipment. ${ }^{89}$ Furthermore, it includes suggestions on facilitating the use of electronic import, export, and transit procedures and reducing human contact to improve the efficiency of customs clearance for essential medical products during the pandemic. ${ }^{90}$

\section{A Comprehensive Multilateral Framework for the Pandemic?}

The current WTO framework lacks a comprehensive set of rules for the prevention and control of a global pandemic. ${ }^{91}$ The relevant rules are fragmented across various multilateral agreements on trade in goods, trade in services, and trade-related intellectual property rights. Therefore, it is time-consuming and laborious to examine the legality of each and every qualitative and normative measure. The EU has issued a lengthy statement elaborating the need for a global solution to cope with the COVID-19 pandemic, a solution that can be provided only by a multilateral trading system, not economic nationalism. It is thus argued here that a new formal agenda for WTO reform is needed, including an initiative for a WTO comprehensive agreement on international pandemic prevention and control and a set of trade-related measures under the WTO framework, to cope with the issues of public health and global pandemic prevention and control. ${ }^{92}$ The failure of the Doha Round of WTO

\footnotetext{
${ }^{90}$ Sela S, Yang A and Zawacki M, Trade Facilitation Best Practices Implemented in Response to the COVID-19 Pandemic (World Bank 2020)

${ }^{91}$ Minyou YU, and Jirong ZHANG. "On the new Agenda of WTO Reform : initiative of a WTO comprehensive agreement on international pandemic prevention and control." International Business Studies, no 4, 2020, p 48.

${ }^{92}$ Ibid.
} 
negotiations and the ongoing crisis in the dispute settlement mechanism, however, remind us that it will be a very arduous task to bring WTO members back to the negotiating table to agree on a uniform agreement dealing with trade measures in relation to global pandemic prevention and control.

\section{PART SIX: CONCLUSION}

The shortages of critical medical equipment and supplies seen during the ongoing COVID-19 pandemic expose the serious flaws in the global supply chain. In response, international society has adopted various trade-restrictive measures, such as temporary export restrictions or prohibitions, as well as a small number of liberalization measures.

Of particular note are the measures referred to as QRs, which are considered unlawful in principle under Art. XI of GATT. However, Art. XI:2(a), Art. XX (General Exception), and Art. XXI (Security Exception) of the same agreement have been used to justify the adoption of these restrictive measures during the pandemic. Furthermore, the SPS Agreement provides for the possibility of applying certain sanitary or phytosanitary measures during a pandemic. In general, so long as export restrictions are non-discriminatory, temporary, and necessary to achieve a certain degree of domestic protection, they are likely to be permissible under existing WTO rules. However, member states must meet a series of transparency obligations in imposing such restrictions.

This paper takes China as an example, investigating the two export-related restrictive measures the country has adopted, namely, export licensing/permit requirements for medical supplies and import prohibitions/restrictions on the wildlife trade. Although the latter is likely permissible under WTO rules, the former may be challenged for resorting to general exceptions, but is probably justifiable under Art. XI:2.

The possibility of adopting trade-restrictive measures by resorting to exceptional rules under the WTO framework may have an adverse impact on the global supply chain and cause harm to vulnerable countries in a time of pandemic. The current pandemic has also led to the emergence of anti-globalization and de-Sinicization sentiments out of concerns over overreliance on China. Although such sentiments are understandable, we believe that the WTO, as the world's major multilateral trade platform, remains the best forum for dealing with problems in the global supply chain under the special circumstances of the pandemic. Accordingly, reforms to the WTO regime with respect to the adoption of traderestrictive measures are urgently needed to promote equitable global access to critical supplies.

In light of the current WTO negotiation deadlock and crisis in the dispute settlement mechanism, WTO members need to affirm the effectiveness of multilateralism for resolving international trade problems. The proposed restrictive application of the exceptions in the GATT rules, increased transparency over the adoption of restrictive measures, and a possible comprehensive multilateral document on trade for pandemic prevention and control would no doubt help to resolve the problems and deficiencies that have been exposed during the COVID-19 pandemic.

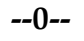

\section{How to cite this article}

Zhao, Y., \& Lin, L. (2021). Trade-restrictive Measures under the WTO Framework in the Context of the COVID-19 Pandemic: The Example of China. American Journal of Trade and Policy,8(1), 71-86. https://doi.org/10.18034/ajtp.v8i1.533 